\title{
A Risk Management Model Applicable To The Administration Of The Research, Development And Innovation (RD\&I) Processes From Occidental Amazon
}

\author{
Ana Paula Pignaton, Marcelo Oliveira, Gabriela Veroneze, and Marcelo Pereira
}

\begin{abstract}
The process of research, development and innovation (RD\&I) is very important for the technological growth of a nation. Because they are activities with a considerable level of uncertainty, they require a lot of planning, with the execution of projects and a robust risk management. In the Western Amazon is one of the largest industrial parks in Brazil, subsidized by tax benefits from Law No. 8,387 / 1991, which also establishes the obligation for companies that manufacture computer goods to allocate part of their revenue for the implementation of projects of Research and Development. Studies show that the results of RD\&I activities carried out in the Western Amazon, as well as in Brazil, are deficient. Thus, this work aimed to present a risk management model that can contribute to a better management of processes related to RD\&I in the Western Amazon. The methodology consisted of a scientific research of applied nature, whose data were collected through bibliographic, documentary and case study research, and later they were analyzed in a qualitative way. It was concluded that the risk management model presented here is a practical manual composed of a detailed procedural rite of great value for managers who want to implement a risk management program in their organizations and, specifically in the case of SUFRAMA, represents a support instrument to guide the management of risks inherent to RD\&I activities developed in the Western Amazon, enhancing its results and contributing to expand the technological development of the region.
\end{abstract}

Index Terms—risk management; research, development and innovation; Western Amazon.

\section{INTRODUCTION}

The technological development of a nation is related to the process of research, development and innovation. Studies show that countries that invest in innovation have better economic indexes and, consequently, quality of life. According to [1], national expenditures on $\mathrm{R} \& \mathrm{D}$ in relation to the gross domestic product (GDP), of countries such as Germany, the United States and Japan are more than double the expenditure observed in Brazil. Therefore, it is essential that developing countries pay attention and invest on research, development, and innovation (RD\&I) process.

The RD\&I process is developed through projects. Projects are tactical instruments for the execution of strategic actions. The success of strategic planning is linked to the projects [2], and institutions must adequately develop and manage their projects to achieve their objectives.
The Western Amazon is the region made up of the states of Amazonas, Acre, Rondônia and Roraima, where is located one of the largest industrial parks in Brazil, the Industrial Pole of Manaus, which was established from the creation of the Manaus Free Trade Zone, and was strengthened with the tax incentives promulgated by Informatics Law [3], which brought in addition, the obligation of companies that manufacturers of computer goods to allocate part of their revenue for the implementation of research and development projects. The Superintendence of the Manaus Free Trade Zone (SUFRAMA) is the body responsible for the management and monitoring of resources related to RD\&I projects and, among other tasks should ensure the efficient application of them.

Organizations of all types and sizes face a range of risks that can affect the achievement of their goals [4]. Thus, risk management should be a central element in the management of the strategy of organizations.

When it comes to project management, risk management is an important component, as it aims to increase the likelihood and impact of positive occurrences and reduce the likelihood and impact of negative occurrences, as follows [5].

The study conducted by [6] showed the need to improve the efficiency of R\&D results in the Manaus Free Trade Zone. Thus, considering that adequate risk management is associated with the success of projects, and that RD\&I projects are naturally endowed with risks, this work presents a risk management model applicable to the management of RD\&I process in the Western Amazon.

\section{LITERATURE REVIEW}

According to [7], experimental research and development (R\&D) refers to the systematic work done to increase the knowledge stock and/or develop new applications of available knowledge. [8] recalls that despite of unanimous recognition, the importance of innovation only gained prominence after the study of the economic growth of nations [9], when the theme technology came to be considered a driving factor of the economy. He points to innovation as the driving force of global change, being the main driver of the development of nations, so that only innovation makes possible for the great leaps of growth of peoples, allowing their differentiation from other countries.

G. Veroneze, Federal University of Amazonas, Brazil (e-mail: gveroneze@ufam.edu.br)

M. Pereira, Eldorado Research Institute, Brazil. (e-mail: marcelo.pereira@eldorado.org.br) 
According to [10], the Frascati Handbook corresponds to the reference document when it comes to R\&D. Its definitions are accepted worldwide, and its principles are based on [11] and [12].

As [13] a Research \& Development project is characterized by dealing with "a strong component of uncertainty regarding its results. The greater the lack of knowledge regarding the expected results, the greater the risk related to the project."

To understand about risk management, it is first necessary to understand the meaning of risk. [14] notes that there is no single definition for risk since it varies according to the context and notes that several authors bring different concepts to the theme. However, in general terms, "risk" has been used to express uncertainty about certain events and their consequences, according to [15]. [16] it presents an interesting definition: it is common to understand "risk" as a possibility of "something not working" but its current concept involves the quantification and qualification of uncertainties, both with regard to "losses" and "gains" about the planned events, either by individuals or by organizations. [17], presents several concepts and terms related to risk management. Among these, it classifies "risk" as the effect of uncertainty on the objectives, and the effect is characterized as a deviation from what is expected, whether positive and/or negative. The concept of "risk management" is also addressed in the guide as "coordinated activities to direct and control an organization about risks."

According to [18], most definitions link risk to uncertainty, so risk is associated to the probability of an event occurring, while uncertainty does not offer the possibility of predicting the occurrence of an event. Several authors suggest replacing the term risk management with uncertainty management $[19$, 20, 21 and 22], because for these authors, uncertainty management is not only a combination of risk and opportunity management, but also concerns how to identify and manage all the sources that give rise to and shape our perceptions of threats and opportunities. Despite this broader understanding related to the management of uncertainties, for conceptualization purposes, this work will deal with the theme (risk and uncertainty management), such as risk management, since it is the term best known and disseminated in the academic and industrial environment.

When it comes to the theme "Risk management" it is essential to mention [4], a standard elaborated with the aim of establishing general guidelines for risk management, with a common approach to any sector or activity, so it can be applied to any type of risk regardless of its nature, and if the consequences are positive or negative. The standard establishes a cross-cutting vocabulary for all areas of risk management, a set of performance criteria, a comprehensive process for identifying, analyzing, assessing and treating risks and guidance on how the risk management process should be integrated into an organisation's management process, as per [23].

The risk management process requires the systematic application of policies, procedures and practices for communication and consultation activities, context determination and evaluation, treatment, monitoring, critical analysis, registration and risk reporting, as well as [24], which also emphasizes how important it is that the risk management process is part of management and decisionmaking, and is integrated in the structure, operations and processes of the organization, and can be applied at the strategic, operational, program or project levels. Project Risk
Management is one of the most stimulating challenges of Project Management, given its complexity, scope, transience, difficulties of technical tools, innovation, bibliographic scarcity, lack of definition of approach, among other factors [25].

\section{Methodology}

This work consists of a scientific research of an applied nature, given its character of practical and descriptive interest, because it seeks to know the reality studied, its characteristics and its problems. The data will be approached qualitatively, and the procedures adopted in their collection will be bibliographic, documentary research and case study.

The work was divided into three stages:

- Bibliographic research;

- Field and documentary research;

- Elaboration of the model.

The instruments used were books, newspapers, magazines, documents, scientific articles, field research script, questionnaire and interview. The collected data were analyzed qualitatively to support the development of the risk management model.

\section{FINDINGS AND DISCUSSIONS}

\section{A. Superintendence of the Manaus Free Trade Zone (SUFRAMA) and the RD\&I process.}

The Superintendence of the Manaus Free Trade Zone (SUFRAMA), a federal authority linked to the Ministry of Economy is responsible for managing and monitoring the application of R\&D resources derived from computer legislation [3, 26 and 27] applied to the Western Amazon, through the sector called General Coordination of Technological Management - CGTEC, which is subordinate to the Adjunct Superintendence of Regional Planning and Development - SAP.

The resources related to RD\&I in the AMOC region, come from the counterpart paid in a compulsory way, by the companies receiving the tax incentives. Briefly, the procedural rite to be followed by companies for granting benefits involves, at the beginning of the process, the presentation of the PPB (Basic Productive Process) and the R\&D Plan (R\&D), and at the end of the process, as a way to prove the execution of the activities described in that plan, the presentation of the RD (Demonstrative Report) according to [27]. The field surveys showed that although SUFRAMA seeks to carry out its activities always in accordance with current standards, there are, of course, some obstacles and opportunities for improvement that need to be treated with due attention. Thus, this study presents the proposal of a risk management model applicable to the management of AMOC's RD\&I process, which, if implemented, can contribute strongly to the improvement of the results of the process.

\section{B. The Risk Management Model}

The implementation of a new process and/or its incorporation into existing processes in an organization is generally faced with obstacles related to a pre-established culture, which can hinder the success of the election. Thus, it is prudent that the project be initiated by parties, consolidated with a smaller target audience, to later be disseminated to the 
rest of the institution. Based on this, this work proposes the execution of a pilot project, where the proposed risk management model is applied and consolidated in AMOC's RD\&I management process.

The model presented here consists of three steps, which follow a flow as shown in Fig. 1.

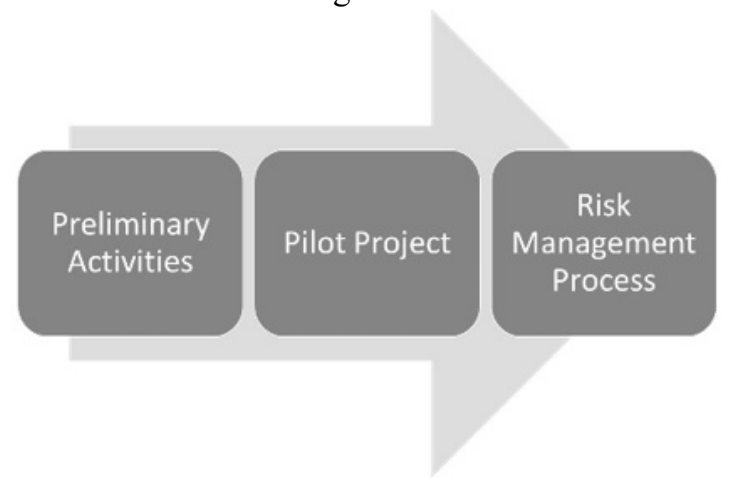

Fig. 1. Flow of the Risk Management program deployment process

\section{B.1. Preliminary Activities}

Preliminary activities must be carried out before the project begins. They correspond to the step-by-step from the decision to make a proactive risk management to the preparation of the pilot project and are represented in Table I.

TABLE I: DESCRIPTION OF PRELIMINARY ACTIVITIES FOR THE IMPLEMENTATION OF THE RISK MANAGEMENT PROCESS

\section{Approval and commitment of senior management}

1.1 Gather information on the significant events that have occurred in recent years that have harmed the organization, as well as missed opportunities;

1.2 Prepare a workshop with senior management to: discuss losses and gains by leaving the organization exposed to uncertainties; to present the expected benefits with risk management; propose the implementation of a risk management program.

\section{Risk management committee and committee}

2.1 Appoint the persons which will be part of the Governance, Risks and Controls Committee (in this case, it is already defined in Ordinance 146/2017: the Superintendent and the Deputy Superintendents);

2.2 Appoint the employees who will compose the Permanent Commission for Risk and Control Management (ideal as people involved in the target process of the pilot project);

2.3 Define roles and responsibilities (already defined in Ordinance 146/2017)

\section{Technical support}

3.1 Provide the hiring of a risk management specialist and to support the conduct of activities;

3.2 Review the previous items.

\begin{tabular}{l} 
4. Learning \\
\hline 4.1 Train the members of the committee and committee on risk \\
management (training, courses, etc.); \\
4.2 Conduct study groups to deepen knowledge on the subject and its \\
laws and regulations; \\
4.3 Conduct technical visits to reference organizations in risk \\
management; \\
4.4. Agree with senior management to promote learning in routine \\
meetings periodically.
\end{tabular}

\section{Risk Management Policy}

5.1 Study the risk management policies of public reference institutions; 5.2 Consult representatives of internal and external stakeholders on risk management needs and expectations in the organisation;

5.3 Define the policy and submit to internal and external consultation (revising if necessary);

5.4 Obtain approval from senior management;

5.5 Disseminate widely with the participation of senior management.

\section{Pilot project}

6.1 Develop a pilot project for the implementation of risk management, together with the committee, committee and technical specialist, based on the guidelines of the risk management policy and the premises of the PMBOK Guide.

\section{B.2. The Pilot Project}

The pilot project will be the guiding document for the implementation of the Risk Management program and should be prepared as a team, with the participation of the committee and risk management committee of SUFRAMA, as well as the technical experts hired. In the pilot project, all processes related to it should be described and documented, according to [5]. Table II summarizes the elements that should compose the pilot project.

TABLE II: DESCRIPTION OF PRELIMINARY ACTIVITIES FOR THE IMPLEMENTATION OF THE RISK MANAGEMENT PROCESS

\begin{tabular}{|c|c|}
\hline $\begin{array}{l}\text { Pilot Project } \\
\text { Components }\end{array}$ & Description \\
\hline Opening Term & $\begin{array}{l}\text { It is the document where the start of the project will } \\
\text { be formalized, and will give the necessary authority } \\
\text { to the project manager. The opening term shall } \\
\text { specify: } \\
\text { * the project manager and his team; } \\
\text { * project start date and its dependencies; } \\
\text { * requirements that meet the needs of } \\
\text { stakeholders; } \\
\text { * justification of the project; } \\
\text { * analytical structure of the project; } \\
\text { * schedule and summarized budget. }\end{array}$ \\
\hline $\begin{array}{l}\text { Scope } \\
\text { Management } \\
\text { Plan }\end{array}$ & $\begin{array}{l}\text { The scope is the document that contains the detailed } \\
\text { description of what will be done in the project, with } \\
\text { the features and functionality necessary to meet the } \\
\text { objectives of the project. This plan should address } \\
\text { the management of the scope of the project (from its } \\
\text { conception, validation and control), as well as the } \\
\text { analytical structure of the project (EAP) and the } \\
\text { strategy of its implementation. The project must run } \\
\text { in full alignment with the scope. }\end{array}$ \\
\hline $\begin{array}{l}\text { Time } \\
\text { Management } \\
\text { Plan }\end{array}$ & $\begin{array}{l}\text { This plan should contain the detailed execution } \\
\text { schedule, with the definition and sequencing of the } \\
\text { activities, estimation of the resources and time } \\
\text { required to execute each of them. }\end{array}$ \\
\hline $\begin{array}{l}\text { Cost } \\
\text { Management } \\
\text { Plan }\end{array}$ & $\begin{array}{l}\text { Estimate of all financial resources necessary to carry } \\
\text { out the activities foreseen in the project, which will } \\
\text { compose the project budget. }\end{array}$ \\
\hline $\begin{array}{l}\text { Quality } \\
\text { Management } \\
\text { Plan }\end{array}$ & $\begin{array}{l}\text { This plan aims to ensure that the project meets the } \\
\text { needs of the client and involves all project activities } \\
\text { throughout its life cycle. }\end{array}$ \\
\hline $\begin{array}{l}\text { Resource } \\
\text { Management } \\
\text { Plan }\end{array}$ & $\begin{array}{l}\text { This plan should contain the estimate of all } \\
\text { necessary resources (human, materials, services, } \\
\text { etc.). It also involves all the management of the } \\
\text { human resources of the project, from the planning } \\
\text { of the team, with the description of the functions, } \\
\text { responsibilities and competencies necessary for the } \\
\text { project, to the monitoring of performance. }\end{array}$ \\
\hline $\begin{array}{l}\text { Communication } \\
\text { and Marketing } \\
\text { Plan }\end{array}$ & $\begin{array}{l}\text { The planning, management and monitoring of } \\
\text { communications and marketing, necessary for the } \\
\text { project should be described in this plan, which } \\
\text { should be robust, since good communication is } \\
\text { fundamental to the success of the project. }\end{array}$ \\
\hline
\end{tabular}




\begin{tabular}{ll}
$\begin{array}{l}\text { Project Risk } \\
\text { Management } \\
\text { Plan }\end{array}$ & $\begin{array}{l}\text { Project risk management includes planning, } \\
\text { identification, analysis, response planning, } \\
\text { implementation of responses and monitoring of } \\
\text { project risks. }\end{array}$ \\
\hline $\begin{array}{l}\text { Procurement } \\
\text { Management } \\
\text { Plan }\end{array}$ & $\begin{array}{l}\text { All planning, conduct and control of acquisitions } \\
\text { should be documented in this plan. }\end{array}$ \\
\hline $\begin{array}{l}\text { Stakeholder } \\
\text { Management } \\
\text { Plan }\end{array}$ & $\begin{array}{l}\text { This plan includes identification and planning for } \\
\text { stakeholder engagement and also addresses the } \\
\text { management and monitoring of this engagement. }\end{array}$ \\
\hline Closing term & Document that will formalize the end of the project. \\
\end{tabular}

\section{B.3. The Risk Management Process}

The proposed risk management process is based on [24] and will take place according to the flow presented in Fig. 2.

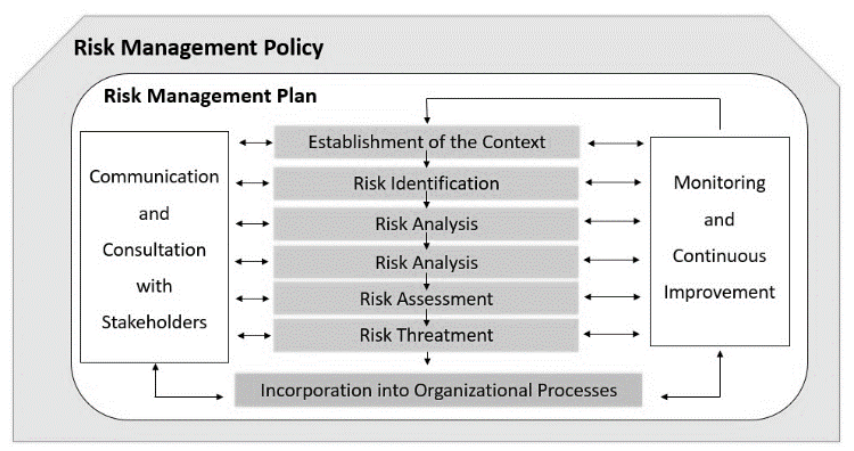

Fig. 2. The risk management process.

Based on the risk management policy, the Risk Management Plan should be prepared, which should be clearly and concisely described the procedures to be followed, according to the flow of Fig. 2, to manage the risks of the SUFRAMA RD\&I process. This plan must be prepared by a technically qualified person with the participation of the committee and risk management committee. It is observed in Fig. 2 that the suggested risk management process consists of five steps and two subprocesses that are part of all of them. The steps are:

a) establishment of the context;

b) identification of risks;

c) risk analysis;

d) risk assessment;

e) Treatment of risks.

The subprocesses of communication and consultation with stakeholders and continuous monitoring and improvement should occur concomitantly with each of the steps, with the particularities that they require, and are fundamental for the smooth running of the process. All stages should take place with the participation of the committee and risk management committee, the technical specialist, as well as people who have greater knowledge about the management of SUFRAMA'S R\&D processes.

\section{B.3.1. Establishment of the context}

The context corresponds to the internal and external environment in which the risk management object is inserted, as well as to the conditions of that environment that can influence in some way the results of the process. To establish the context, one must understand these environments well and map parameters and criteria to be considered in the risk management process, such as:

- identify which objectives should be achieved;
- identify the work processes relevant to the achievement of the objectives;

- identify the people involved in these processes and specialists in the area;

- map the main internal and external factors that can affect the achievement of objectives (people, information systems, organizational structures, legislation, resources, stakeholders, etc.).

SWOT Analysis (Strengths, Weaknesses, Opportunities, Threats), together with PESTLE Analysis (Political, Economic, Social, Technological, Legal Environmental) and brainstorming are good tools for this process. It is also suggested the preparation and application of questionnaires and conducting working groups to gather information from stakeholders.

\section{B.3.2 Identification of risks}

At this stage, a wide survey of uncertainties, risk factors and their consequences should be made, which can affect, both positively and negatively, the achievement of the objectives of SUFRAMA's RD\&I management process. It is suggested that the identification of risks be done according to the following steps:

- map the oversight, coordination, sector, and process involved;

- clearly identify the objectives to be achieved;

- relate the activities and tasks to be performed to achieve the objectives;

- list, for each activity and task, uncertainties and risk factors may impact the achievement of the objectives;

- describe how each uncertainty impacts the objective associated with it.

The tools used to identify risks can be brainstorming, analysis of historical data, expert opinions, theoretical analysis, technical visits, interviews, among other sources of information.

The largest possible number of risks/uncertainties should be raised, and the data should be recorded in a specific spreadsheet.

\section{B.3.3. Risk analysis}

Risk analysis is the time to understand the risks/uncertainties and determine their level of risk. This is a continuation of the previous stage and therefore, should be performed preferably by the same team.

Considering that risk is a function of the measure of probability and consequences/impacts on objectives, it is part of determining the level of risk based on risk matrices and probability and impact scales. Since SUFRAMA is in the early stages of the risk management implementation process, it is recommended that more simplified tools be used to facilitate employee understanding of the process. In the future, with the maturation of the process, there is a natural tendency to evolve in the complexity of the procedures and tools employed. So, according to [28] this step encompasses the following steps:

- assess the impact of the risk on the objective;

- assess the probability of the risk occurring;

- define the level of inherent risk (disregarding control measures) based on the risk matrix.

For this, Tables III and IV present the probability and impact scale models, respectively, to be used in the pilot project. 
TABLE III - PROBABILITY SCALE MODEL

\begin{tabular}{ccc}
\hline Probability & $\begin{array}{c}\text { Description of probability, disregarding } \\
\text { controls }\end{array}$ & Weight \\
\hline Too low & $\begin{array}{c}\text { It's unlikely. In exceptional situations, the } \\
\text { event may even occur, but nothing in the } \\
\text { circumstances indicates this possibility. }\end{array}$ & 1 \\
\hline Low & $\begin{array}{c}\text { It's rare. Unexpectedly or casually, the } \\
\text { event may occur, as circumstances do not } \\
\text { indicate this possibility. }\end{array}$ & 2 \\
\hline Hverage & $\begin{array}{c}\text { It's possible. Somehow, the event may } \\
\text { occur, as circumstances moderately } \\
\text { indicate this possibility. }\end{array}$ & 5 \\
\hline & $\begin{array}{c}\text { That's likely. As expected, the event may } \\
\text { occur, as the circumstances strongly } \\
\text { indicate this possibility. }\end{array}$ & 8 \\
\hline Very High & $\begin{array}{c}\text { Pretty much right. Unequivocally, the } \\
\text { event will occur. The circumstances } \\
\text { clearly indicate this possibility. }\end{array}$ & 10 \\
\hline
\end{tabular}

TABLE IV - IMPACT SCALE MODEL/CONSEQUENCES

\begin{tabular}{llc}
\hline Impact & $\begin{array}{l}\text { Description of probability, disregarding } \\
\text { controls }\end{array}$ & Weight \\
\hline Too low & $\begin{array}{l}\text { Minimum impact on objectives (strategic, } \\
\text { operational, information/ communication/ } \\
\text { disclosure or compliance). }\end{array}$ & 1 \\
\hline Low & Small impact on objectives (idem). & 2 \\
\hline Middle & $\begin{array}{l}\text { Moderate impact on objectives (idem), but } \\
\text { recoverable. }\end{array}$ & 5 \\
\hline High & $\begin{array}{l}\text { Significant impact on objectives (idem), } \\
\text { difficult to reverse. }\end{array}$ & 8 \\
\hline Too High & $\begin{array}{l}\text { Catastrophic impact on objectives (idem), } \\
\text { irreversibly. }\end{array}$ & 10 \\
\hline
\end{tabular}

At first, the Inherent Risk Level (IRL) must be defined, in the other words, the level of risk before considering the control measures adopted by the institution to reduce the probability of the event or its impacts on objectives. In this work, the IRL results from the multiplication of probability with impact (IRL = Probability $x$ Impact). Fig. 3 and Fig. 4 shows, respectively, the risk matrix and the risk rating scale model to be used.

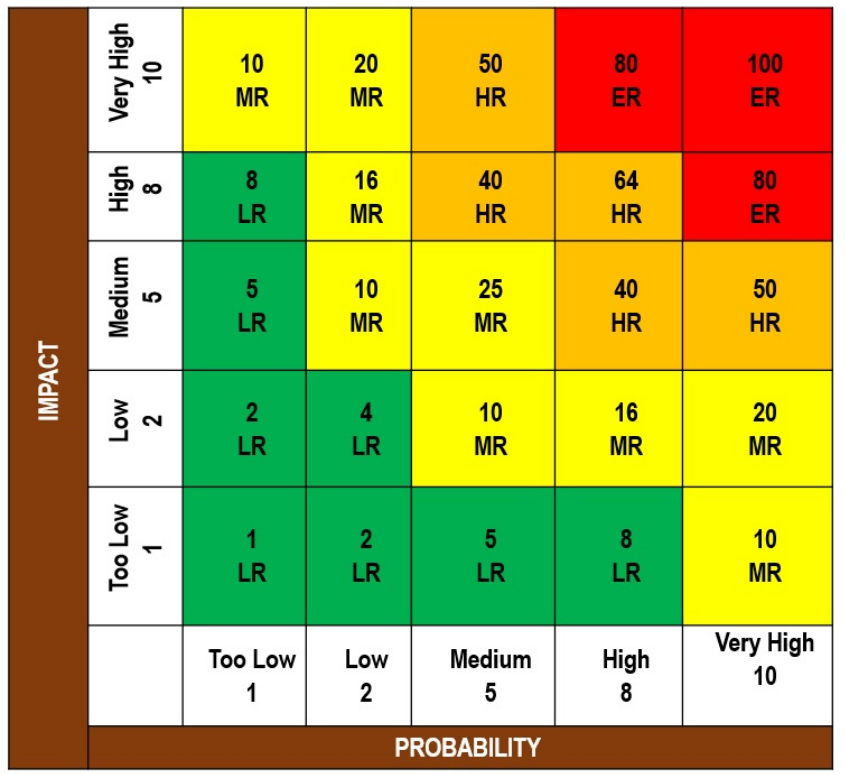

Fig. 3 - Risk Matrix Model

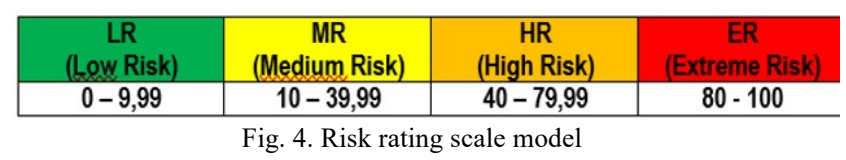

After the survey of the IRL, starts the second stage of the risk analysis, which is the classification of the residual risk levels (RRL). The RRL corresponds to the level of risk that still remains after considering the effect of the control measures adopted by management to reduce the likelihood and impact of risks, including internal controls and other actions. According to [29], control measures are equivalent to actions established through policies and procedures, implemented at all levels of the organization, at various stages within the organizational process and in the technological environment, which help ensure compliance with the guidelines determined by management to mitigate risks.

The verification of the effect of control measures on risk mitigation can be done by estimating the effectiveness of each control and determining a Confidence Level (CL), by analyzing the attributes of the design and implementation of the control, as shown in the illustrative example presented in Table 5 below.

\begin{tabular}{|c|c|c|}
\hline $\begin{array}{l}\text { Level of } \\
\text { Trust }\end{array}$ & $\begin{array}{l}\text { Evaluation of the design and } \\
\text { implementation of controls } \\
\text { (Control attributes) }\end{array}$ & $\begin{array}{r}\text { Control } \\
\text { Risk (RC) }\end{array}$ \\
\hline $\begin{array}{l}\text { Nonexistent } \\
\begin{array}{c}\mathrm{NC}=\mathbf{0} \% \\
(\mathbf{0 . 0})\end{array}\end{array}$ & $\begin{array}{l}\text { Non-existent, poorly designed, or } \\
\text { poorly implemented controls, that is, } \\
\text { non-functional. }\end{array}$ & $\begin{array}{l}\text { Too High } \\
\qquad 1,0\end{array}$ \\
\hline $\begin{array}{c}\mathrm{NC}=20 \% \\
(0.2)\end{array}$ & $\begin{array}{l}\text { Controls have ad hoc approaches, tend } \\
\text { to be applied on a case-by-case basis. } \\
\text { Responsibility is individual, with a } \\
\text { high degree of confidence in people's } \\
\text { knowledge. }\end{array}$ & High \\
\hline $\begin{array}{c}\mathrm{NC}=40 \% \\
(0.4)\end{array}$ & $\begin{array}{l}\text { Implemented controls mitigate some } \\
\text { aspects of risk, but do not address all } \\
\text { relevant aspects of risk due to } \\
\text { deficiencies in the design or tools used. }\end{array}$ & $\begin{array}{l}\text { Middle } \\
0,6\end{array}$ \\
\hline $\begin{array}{c}\mathrm{NC}=60 \% \\
(0.6)\end{array}$ & $\begin{array}{l}\text { Controls implemented and supported } \\
\text { by appropriate tools and although } \\
\text { subject to improvement, mitigate the } \\
\text { risk satisfactorily. }\end{array}$ & Low \\
\hline $\begin{array}{c}\mathrm{NC}=80 \% \\
(0.8)\end{array}$ & $\begin{array}{l}\text { Implemented controls can be } \\
\text { considered the "best practice," } \\
\text { mitigating all relevant aspects of risk. }\end{array}$ & Very Low \\
\hline
\end{tabular}

To perform this step, you must adopt the following steps:

a) determine the level of confidence based on the attributes of Table 5;

b) determine the risk of control, that is, the possibility that the controls adopted by management are not effective to prevent, detect and allow to correct, in a timely manner, the occurrence of events that may affect the objectives (Control risk $=1$ - Confidence level);

c) estimate the level of residual risk (NRR). For this, the inherent risk level (NRI) is deduced from the inherent risk level (NRI), the percentage of confidence (NC) attributed to the control, which is equivalent to multiplying the NRI by the RC, using the following formula: "Residual risk level = Inherent risk level x Control risk."

Corroborating with [30], the documentation of the risk analysis stage generally includes:

a) the approach or method of analysis used, the sources of information consulted and the participants in the analysis process;

b) the specifications used for risk probability and impact ratings;

c) the probability of occurrence of each event, the severity or magnitude of the impact on the objectives and their 
description, as well as considerations in the analysis of these elements;

d) the description of existing internal controls, considerations regarding their effectiveness and the risk of control;

e) the inherent and residual level of risk.

Once the risk analysis has been completed, the whole process should be documented in order to ensure traceability of the information.

\section{B.3.4 Risk Assessment}

Risk assessment will assist managers in decision-making, based on the results of the risk analysis. In this way, the steps for risk assessment are:

- Map, in the risk matrix, what are the key risks and define their respective guardians?

- Identify risks/uncertainties whose levels are above the tolerable limit;

- identify, for risks above the limit, their sources, causes and possible consequences on the organisation;

- identify the risks that are within and/or below the exposure limit;

- define which risks/uncertainties need treatment and what priority is to do so;

- decide whether a particular activity should be carried out or discontinued;

- whether control measures should be implemented or if they already exist, whether they should be changed, maintained, or eliminated.

The risk assessment proposed in this study will be supported on the criteria table for prioritization and treatment of risks presented in Table VI.

TABLE VI - GUIDELINES FOR PRIORITIZATION AND TREATMENT OF RISKS Risk

Level Criteria for prioritization and treatment of risks

ER Risk level far beyond the tolerable limit. Any risk at this level should be reported to the governance and the general superintendent and have an immediate response. Postponement of measures only with the authorization of the maximum leader.

HR Risk level beyond the tolerable limit. Any risk at this level should be reported to the general superintendent and act within a specified period. Postponement of measures only with the authorization of the deputy superintendent.

MR Level of risk within the tolerable limit, but with the potential to expand to high risk. Risks at this level require relatively simple control measures, which can be defined at the level of coordination. It requires specific monitoring activities and coordination attention in maintaining responses and controls to maintain risk at this level, or reduce it without additional costs.

LR Risk level within the tolerance limit. Generally, it does not require additional control measures, but it is possible that there are opportunities for greater return that can be explored by taking more risks, evaluating the cost-benefit ratio, such as lowering the level of controls.

Once the risk assessment is complete, the results of the work should be documented in a spreadsheet that will contain a detailed list of the risks that require treatment, with their respective classifications and priorities. This document is an important management tool.

\section{B.3.4.1 Risk Guardians}

Risk guardians are the people selected to be responsible for managing the organization's key risks. The key risks are those that require greater attention from senior management, due to their potential to cause damage to the institution. In this way, guardians should be appointed by the risk committee, which will establish their respective missions and responsibilities (together with the risk management committee and technical expert) by signing a Term of Commitment. For recognition and greater motivation of risk guardians, it is suggested to hold an induction ceremony (it may be at the same presentation ceremony as the pilot project), with the participation of all CGTEC employees, where the commitment, importance and responsibility of them (guardians) and all employees with the risk management of the institution should be reinforced.

\section{B.3.5 Risk treatment}

At the end of the risk assessment stage, the treatment of those who need it should be defined. That is, it is necessary to define the control measures that will be improved and/or implemented in order to modify the levels of each risk/uncertainty, through the preparation of the action plans, which should contain the respective responsible, deadlines and activities. In this way, the working groups should once again meet and establish, based on existing information, the best alternative for risk treatment, taking into account their cost-benefit. Briefly, the steps in this step are:

- identify possible control measures for each risk;

- evaluate the feasibility of implementing these measures (cost-benefit, technical feasibility, timeliness, side effects of treatment, etc.);

- decide which control measures will be implemented;

- develop a risk treatment plan (as 5W2H Technique), for inclusion in institutional plans.

The risk treatment plan shall, as [24] define the order of priority for the implementation of each control measure, as well as identify:

a) the justification for the selection of treatment options, including the expected benefits;

b) those responsible for approving and implementing the plan;

c) the proposed actions;

d) the resources required, including contingencies;

e) performance measures;

f) restrictions;

g) the reports and monitoring required;

h) execution schedule.

It is important to point out that there are different types of responses to the risks that can be adopted by the institution. In this work, corroborating with [31], for negative risks/uncertainties (Threats), the following types were proposed:

- avoid the threat;

- reduce the threat;

- transfer the risk;

- accept the risk.

For the opportunities, the following types of response were proposed:

- share risk; 
- explore opportunity;

- improve opportunity;

- accept the risk.

Treatment plans should be registered in an electronic information system, preferably the same risk registration system, equipped with resources that facilitate the monitoring of the evolution of action plans and ensure data security, such as sending notifications, issuing periodic reports, traceability of users and modifications, security backup, among others.

\section{B.3.6 Monitoring and Continuous Improvement}

Monitoring the performance of the risk management plan is a fundamental step for the success of the project, as it will allow the verification, correction and/or improvement of the process in a timely manner and will also enable the analysis of successes and failures, as well as the promotion of lessons learned. Monitoring has three strands:

- the operation of the Risk Management System;

- the implementation and results of risk treatment;

- the evolution of the level of risks that did not require treatment.

Within these aspects, there are three types of monitoring to be considered:

a) continuous monitoring - aims to continuously measurement the performance of risk management, through key risk indicators, analysis of the pace of activities, operations or current flows compared to what would be necessary to achieve objectives or maintain activities within the established risk criteria. This should be carried out by managers, supervisors, and guardians of the respective risks, with the help of the SGR, through the issuance of notifications and alert messages, alignment meetings and feedback, system updates, etc.

b) audits - aims to evaluate systemic aspects, that is, focusing on the structure and process of risk management. It should be carried out periodically by properly trained internal and external auditors, with the publication of a final report.

c) critical analysis - the data generated by continuous monitoring and audits should be recorded, analyzed and presented to the risk management committee for consideration of critical analysis in periodic meetings, which should be recorded in specific minutes. Action plans from critical analysis meetings should be registered in the risk management system (SGR).

d) assessment of the maturity of risk management - aims to periodically assess the existing capacities in the institution, with regard to leadership, policies and strategies, preparation of people for risk management, as well as the use of these capabilities to the processes and partnerships, and the results obtained in improving the performance of the organization in fulfilling its institutional mission of generating value for stakeholders efficiently and effectively transparency and accountability, and compliance with legal requirements. This is a specific process, similar to an audit, but with a different particularities, which will allow the identification of the current level of maturity (baseline) of the institution, as well as the monitoring of its evolution over time. As in the audit, the maturity assessment process should take place following a predetermined systematic and with the issuance of result's reports. [28] has developed a very interesting maturity assessment model and can be used as a reference for application in SUFRAMA.

The treatment plans from the monitoring processes will allow the gradual and successive evolution of the system, thus promoting the continuous improvement of the system.

\section{B.3.7 Communication and consultation with stakeholders}

The success of any project depends on a good flow of communication between the parties involved. Therefore, a robust Risk Communication Plan should be prepared by a qualified professional with the participation of stakeholders, in order to maintain an effective channel of communication between stakeholders in the internal and external context. It is important to note that the communication flow should occur in the vertical (from the base to senior management and vice versa) and horizontal (between employees of different sectors/processes). Among the actions to be contemplated by the communication plan, in line with [24], are:

- identify stakeholders, map their interests, expectations and legitimate needs, and estimate their power of influence;

- ensure that these aspects, as well as the different views of stakeholders, are understood and considered in the definition of criteria for risk management;

- keep the committee, committee, guardians and risk managers informed about the execution of the plan and the communications and consultations carried out;

- incorporate information on risk management, its performance and its effectiveness in management and accountability reports directed to society and control bodies;

- implement communication through visual information management, with the preparation and layout of risk maps among other visual communication strategies;

- implement a continuous training program for managers, servers and employees to apply principles, guidelines and techniques for risk management;

- develop a strategy to assist the expansion of the incorporation of risk management to organizational processes;

- keep up-to-date information on risk management at SUFRAMA's headquarters and on the Internet, available for public consultation (except sensitive information).

\section{B.3.8 Risk management $x$ organizational management}

"Risk management should be part of all processes and decision-making at all levels of the organization. Creating the capacity to deal with risks throughout the organization, in a structured, systematic and timely manner, expands the capacity to create, protect and deliver value, with positive repercussions on the perception of stakeholders" [32].

The introduction of risk management represents a considerable organizational change, so it needs to be based on good planning with execution well aligned with it. The pilot project presented in this work represents a prototype, to be tested, consolidated, and improved within the R\&D management process of SUFRAMA, to later be expanded to the entire organization. Therefore, when SUFRAMA understands that the process is mature enough and that the 
time has come to spread it, a plan should be drawn up to incorporate risk management into organizational processes.

\section{CONCLUSION}

The proposed risk management model is a practical manual composed of a detailed procedural rite of great value for managers who want to implement a risk management program in their organizations and, specifically in the case of SUFRAMA, represents a support tool to guide the management of risks inherent to RD\&I activities developed in the Western Amazon, enhancing its results and contributing to expand the technological development of the region.

\section{REFERENCES}

[1] Institute of Applied Economic research. "Radar: technology, production and foreign trade". Directorate of Studies and Sectoral Policies of Innovation and Infrastructure - N. 48 (Dec.2016). Brasilia: IPEA, 2016. Available

from: http://www.ipea.gov.br/portal/images/stories/PDFs/radar/20170110_ra dar 48.pdf, accessed: 13/05/2019.

[2] Valle, André. "Fundamentals of project management". André Bittencourt of Valle... [et. Al]. - 3 ed. - Rio de Janeiro: FGV Publishing House, 2014

[3] Brazil. Law No. 8,387 of December 30, 1991. It gives new wording to $\S 1$ of art. 3rd to the arts. 7 and 9 of Decree-Law No. 288 of February 28, 1967, to the caput of art. 37 of Decree-Law No. 1,455 of April 7, 1976 and art. 10 of Law No. 2,145 of December 29, 1953, and makes other arrangements. Available in: http://www.planalto.gov.br/ccivil_03/LEIS/L8387.htm, accessed on 10/12/2019.

[4] ABNT (2009) ABNT NBR ISO 31000 Risk Management - Principles and Guidelines. Brazilian Association of Technical Standards.

[5] "A guide to the project management body of knowledge" (PMBOK guide), Fifth edition. Pennsylvania: Project Management Institute, Inc., 2013. ISBN: 978 1935589-67-9.

[6] Cavalcante, Marcelo Clinger Vieira. "Research and development as a tool of national public policies of science and technology: a case study of the efficiency of computer law in the Manaus free zone through data envelopment analysis". Dissertation presented to the graduate program in production engineering of the Federal University of Amazonas (UFAM). Manaus - AM, 2017.

[7] Organization for Economic Cooperation and Development. Frascati Manual 2015: Guidelines for Collecting and Reporting Data on Research and Experimental Development, The Measurement of Scientific, Technological and Innovation Activities. OECD Publishing: Paris, 2015. Available from: $<$ http://dx.doi.org/10.1787/9789264239012-en>. Accessed: 21 Apr. 2019.

[8] Varella, Sergio R. D. Medeiros, Jefferson B. S. Junior, Mauro T. S "The Development of Schumpeterian Innovation Theory". XXXII National Meeting of Production Engineering Sustainable Development and Social Responsibility: The Contributions of Production Engineering Bento Gonçalves, RS, Brazil, October 15-18, 2012.

[9] Schumpeter, J. "The Theory of Economic Development". Harvard University Press, Cambridge Massachusetts, 1934.

[10] Angeloni, M., Homma, R., Athayde Filho, L., Cosentino. "Information and Knowledge Management in Research and Development Projects - A Case Study". Iberoamerican Journal of Strategic Management (IJSM), North America, 15, Mar. 2016. Available

at: $<$ http://www.revistaiberoamericana.org/ojs/index.php/ibero/article/v iew/2299>. Date accessed: 19 Jul. 2019.

[11] OECD, OECD and FINEP (2015). Organization for Cooperation and Development, Organization for Economic Cooperation and Development, Financier of Studies and Projects (2005) - Oslo Manual - Proposal of Guidelines for Data Collection and Interpretation on Innovation. Financier of Studies and Projects. Rio de Janeiro: ART/FINEP. Available in: http://www.finep.gov.br/images/afinep/biblioteca/manual_de_oslo.pdf,accessed: 12/01/2020.

[12] Brazil. Law 11.196/05 - Law of Good, of November 21, 2005. It deals with the granting of tax incentives to legal entities. Available in: http://www.planalto.gov.br/ccivil_03/_ato20042006/2005/lei/111196.htm,accessed: 12/01/2020.

[13] Pinheiro, Andréia Azevedo et al. "Methodology for managing research and development projects focused on products: a proposal". Rev. Adm. Public [online]. 2006, vol.40, n.3 [cited 2020-06-14], pp.457-478. Available from: $<$ http://www.scielo.br/scielo.php?script=sci_arttext\&pid=S0034$76122006000300007 \& \operatorname{lng}=\mathrm{en} \& \mathrm{nrm}=\mathrm{iso}>$. ISSN $1982-3134$. https://doi.org/10.1590/S0034-76122006000300007.

[14] Doi, Anderson. "Management of corporate risks in small and medium-sized enterprises. Analysis of a national it company". Dissertation presented to the Graduate Program in Professional Master's degree in entrepreneurship of the Department of Administration of the Faculty of Economics, Administration and Accounting of the University of São Paulo (USP). São Paulo - SP, 2017.

[15] Raz, T.; Rilson, D. "A comparative review of risk management standards". Risk Management: In the International Journal, v. 7, n.4, p.53-66, 2005. Disponible in: http://www.risk-doctor.com/pdf-filesissue.pdf. Accessed: 30/07/2019.

[16] IBGC - Brazilian Institute of Corporate Governance. "Guidance for Corporate Risk Management”. São Paulo:IBGC, 2007.

[17] ISO Guide 73:2009 Risk management Vocabulary.

[18] Vieira, Darli R.; Vieira, Raimundo K.; Chain, Milena C.; Bravo, Alencar.; "Model for managing uncertainty in aeronautics projects". International Journal of Product Lifecycle Management, Vol. 10, No. 3, 2017, available at: https://www.inderscienceonline.com/doi/abs/10.1504/IJPLM.2017.0 87573, accessed: 14/01/2020.

[19] Foote, N.W., Galbraith, J., Hope, Q. and Miller, D. (2001) "Making solutions the answer", The McKinsey Quarterly, Vol. 3, No. 1, pp.8493.

[20] Jaafari, A. (2001) "Management of risks, uncertainties and opportunities on projects: time for a fundamental shift", International Journal of Project Management, Vol. 19, No. 2, pp.89-101.

[21] Van den Bos, K. and Lind, E.A. (2002) "Uncertainty management by means of fairness judgments", Advances in Experimental Social Psychology, Vol. 34, No. 1, pp.1-60.

[22] Ward, S. and Chapman, C. (2003) "Transforming project risk management into project uncertainty management", International Journal of Project Management, Vol. 21, No. 2, pp.97-105.

[23] Purdy, G. (2010). "ISO 31000:2009—Setting a New Standard for Risk Management". Risk Analysis, 30(6), 881-886. Available from: https://doi.org/10.1111/j.1539-6924.2010.01442.x, 27/08/2019.

[24] ABNT NBR ISO 31000:2018 - Risk Management - Guidelines. Brazilian Association of Technical Standards.

[25] Rovai, Ricardo Leonardo. "Structured model for risk management in projects: study of multiple cases" [thesis]. São Paulo:, Polytechnic School; 2005 [cited 2020-06-14]. doi:10.11606/T.3.2005.tde01092006-180244.

[26] Brazil. Decree No. 6,008 of December 29, 2006. Regulates $\S 6$ of art. 7 of Decree-Law No. 288, of February 28, 1967, art. 2 of Law No. 8,387 of December 30,1991, and Art. $4^{\circ}$ of Law No. 11,077, of December 30, 2004, which deal with the tax benefit granted to companies that produce computer goods in the Manaus Free Trade Zone that invest in research and development activities in the Amazon, and provides other measures. Available from: http://www.suframa.gov.br/download/legislacao/federal/DECRETO $\% 20 \mathrm{~N} \% \mathrm{C} 2 \% \mathrm{BA} \% 206008, \% 2029$ dez_2006.pdf, accessed: 07/01/2020.

[27] Brazil. Resolution 71 of 6 May 2016. It regulates the fulfillment of obligations related to investments in research and development activities in the Western Amazon, established for companies that produce computer assets benefited under the Manaus Free Trade Zone.

[28] Brazil. Ministry of Transparency and Comptroller General of the Union. Risk Management Methodology. Brasília, DF, 2018.

[29] The Committee of Sponsoring Organizations of The Treadway Commission - COSO. Internal Control: Integrated Structure: Executive Summary and Structure. Translation: PriceWatherhouseCoopers and Institute of Internal Auditors of Brazil, São Paulo, 2013. Available from: $<$ http://www.iiabrasil.org.br/new/2013/downs/coso/COSO ICIF 20 13 Sumario Executivo.pdf $>$. Access: January/2020.

[30] Brazil. Court of Auditors of the Union. "TCU Risk Management 
Manual”. Brasília, DF, 2018.

[31] Bermejo, Paulo H. de Souza. et. al. "ForRisco: a practical guide for risk management in public institutions". Brasília/DF: Editor Evobiz, 2019. Available

https://issuu.com/next_unb/docs/ebook_forrisco_2a_edicao, accessed on $14 / 02 / 2020$.

[32] Brazil. Court of Auditors of the Union. "10 steps to good risk management. Brasília: TCU, Secretariat of Methods and Support to External Control (Semec), 2018. 31 p.: il.

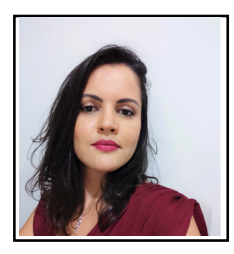

Ana Paula Pignaton is a student in the master's Program in Production Engineering at Federal University of Amazonas, who was born in Paracatu/MG, on May 09, 1985. She has completed and her bachelor's degree at the Faculty of the Northwest of Minas, Paracatu/MG, Brazil, 2010, in Environmental Engineering and after she concluded her post-graduation studies in Occupational Safety Engineering at the University of São Paulo, São Paulo/SP, Brazil, 2013. She has worked as environmental and safety engineering at mining companies.

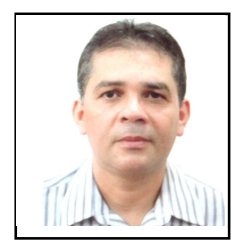

Marcelo Oliveira is an Adjunct Professor, Department of Production Engineering and member of Master Program in Production Engineering, Federal University of Amazonas. He has published several Research Papers related to Engineering area.

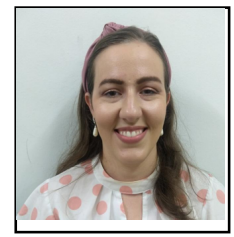

Gabriela Veroneze is an Adjunct Professor, Department of Production Engineering and member of Master Program in Production Engineering, Federal University of Amazonas. She has published several Research Papers related to Engineering area.

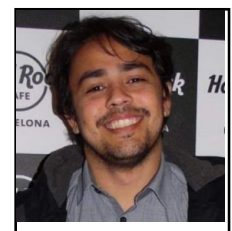

Marcelo Pereira is a Product Management Specialist in Eldorado Research Institute using lean/agile methodologies to develop new systems and manage collaborative teams. 